\title{
Assessment of Coalbed Gas Resources of the Kalahari Basin Province of Botswana, Zimbabwe, and Zambia, Africa, 2016
}

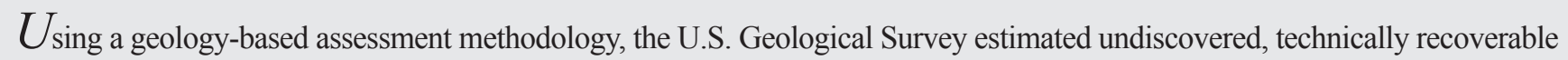
mean resources of 4.5 trillion cubic feet of coalbed gas in the Kalahari Basin Province of Botswana, Zambia, and Zimbabwe, Africa.

\section{Introduction}

The U.S. Geological Survey (USGS) completed an assessment of undiscovered, technically recoverable continuous (unconventional) coalbed gas resources within the Kalahari Basin Province (fig. 1), a geologically complex region of approximately 648,670 square kilometers in Botswana, Zambia, and Zimbabwe. As much as 1,500 meters (m) of Lower Permian sedimentary rocks are present in the Kalahari Basin Province. Coals are present in the Permian Ecca Group. Thickness of the coal-bearing zone ranges from 500 to $550 \mathrm{~m}$ with net coal thickness ranging from 55 to $125 \mathrm{~m}$. Individual coalbeds range from $1 \mathrm{~m}$ to as much as $30 \mathrm{~m}$ thick.

Twenty-six coalbed gas exploration wells have been drilled in the Kalahari Basin Province, and several test wells in Botswana and Zimbabwe reported recoverable gas content or production (IHS Markit ${ }^{\mathrm{TM}}$, 2015; McConachie, 2015; Dowling, 2016). Gas contents are as much as 9.5 cubic meters per ton (334 standard cubic feet per ton) with gas content increasing with depth.

\section{Total Petroleum System and Assessment Units}

For the Kalahari Basin Province, the USGS defined the Permian Composite Total Petroleum System (TPS) and the Kalahari Coalbed Gas Assessment Unit (AU) within this TPS. Coalbed gas production tests from several wells in the province provide limited but good evidence that this petroleum system is viable. Coalbed gas is known to exist in the Kalahari and Zambezi Basins of Botswana, Zambia, and Zimbabwe (Dowling and others, 2016).
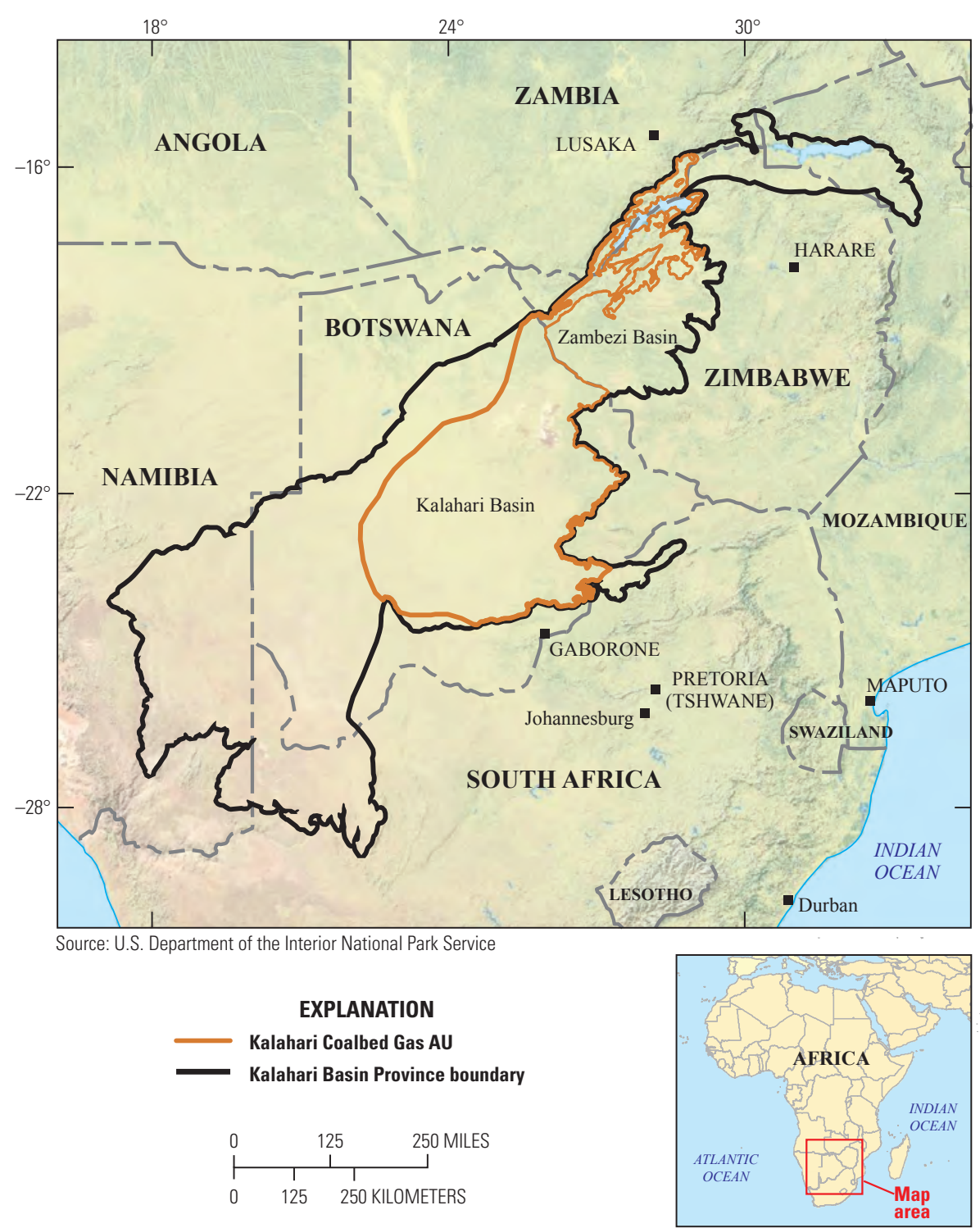

Figure 1. Location of the Kalahari Basin Province and the coalbed gas assessment unit (AU) defined in this study.

The Kalahari Coalbed Gas AU is defined as an area containing thick coals in the Ecca Group and where the coals are less than 1,800 m below the surface. Coals in the Zambia and Zimbabwe parts of the province (also called the Zambezi Basin) range from subbituminous to medium-volatile bituminous coal to highvolatile bituminous, whereas coal rank in the Botswana part of the Kalahari Basin 
Province is high-volatile bituminous (Cairncross, 2001). Coals in Botswana exhibit vitrinite reflectance $\left(R_{0}\right)$ values ranging from 0.5 to 0.7 percent $R_{0}$, a high ash content averaging 39 percent, and sulfur content averaging 0.45 percent. Coalbeds in Botswana have been thermally elevated in rank by dolerite intrusions within the Ecca Group, whereas in Zimbabwe, there are few dolerite intrusions to influence coal rank. Kalahari Basin (Botswana) coals contain thermogenic methane, whereas Zambezi Basin (Zambia and Zimbabwe) coals contain biogenic gas (low-rank coals) and thermogenic gas (high-rank coals).

Assessment input data for the Kalahari Coalbed Gas AU are shown in table 1. Well drainage areas, estimated ultimate recoveries, and success ratios are guided by U.S. coalbed gas analogs.

\section{Undiscovered Resources Summary}

The USGS quantitatively assessed coalbed gas resources within one coalbed gas assessment unit in the Kalahari Basin Province (table 2). For coalbed gas resources, the estimated mean totals for the Kalahari Coalbed Gas AU are 4,504 billion cubic feet of gas (BCFG), or 4.5 trillion cubic feet of gas, with an F95-F5 range from 622 to $11,721 \mathrm{BCFG}$.

Table 1. Key assessment input data for one assessment unit in the Kalahari Basin Province, Africa.

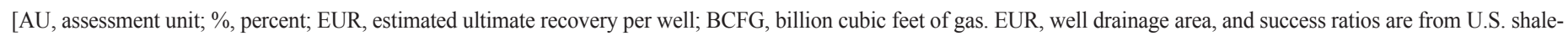
gas and shale-oil analogs. The average EUR input is the minimum, median, maximum, and calculated mean. Shading indicates not applicable]

\begin{tabular}{|l|c|c|c|c|}
\hline \multirow{2}{*}{\multicolumn{1}{c|}{ Assessment input data }} & \multicolumn{2}{c|}{ Kalahari Coalbed Gas AU } \\
\cline { 2 - 5 } & Minimum & Mode & Maximum & \multicolumn{2}{c|}{ Calculated mean } \\
\cline { 2 - 5 } & 10,000 & $4,000,000$ & $80,000,000$ & $18,003,333$ \\
\hline Potential production area of AU (acres) & 40 & 80 & 80 & 35 \\
\hline Average drainage area of wells (acres) & 10 & 0.08 & 0.3 & 21.7 \\
\hline Success ratios (\%) & 0.04 & & 0.092 \\
\hline Average EUR (BCFG) & 1.0 & & \\
\hline AU probability & & & \\
\hline
\end{tabular}

Table 2. Assessment results for one assessment unit in the Kalahari Basin Province, Africa.

[BCFG, billion cubic feet of gas; MMBNGL, million barrels of natural gas liquids. Results shown are fully risked estimates. For gas accumulations, all liquids are included in the NGL (natural gas liquids) category. F95 represents a 95-percent chance of at least the amount tabulated; other fractiles are defined similarly. Fractiles are additive under the assumption of perfect positive correlation. Shading indicates not applicable]

\begin{tabular}{|c|c|c|c|c|c|c|c|c|c|c|}
\hline \multirow{3}{*}{$\begin{array}{l}\text { Total petroleum system } \\
\text { and assessment unit (AU) }\end{array}$} & \multirow{3}{*}{$\begin{array}{c}\mathrm{AU} \\
\text { probability }\end{array}$} & \multirow{3}{*}{$\begin{array}{c}\text { Accu- } \\
\text { mulation } \\
\text { type }\end{array}$} & \multicolumn{8}{|c|}{ Total undiscovered resources } \\
\hline & & & \multicolumn{4}{|c|}{ Gas (BCFG) } & \multicolumn{4}{|c|}{ NGL (MMBNGL) } \\
\hline & & & F95 & F50 & F5 & Mean & F95 & $\mathrm{F} 50$ & F5 & Mean \\
\hline \multicolumn{11}{|c|}{ Permian Composite Total Petroleum System } \\
\hline Kalahari Coalbed Gas AU & 1.0 & Gas & 622 & 3,523 & 11,721 & 4,504 & 0 & 0 & 0 & 0 \\
\hline Total undiscovered resources & & & 622 & 3,523 & 11,721 & 4,504 & 0 & $\mathbf{0}$ & $\mathbf{0}$ & $\mathbf{0}$ \\
\hline
\end{tabular}

\section{References Cited}

Cairncross, Bruce, 2001, An overview of the Permian (Karoo) coal deposits of southern Africa: Journal of African Earth Sciences, v. 33, nos. 3-4, p. 529-562.

Dowling, G.J., 2016, CBM potential of RSA, Botswana \& Zimbabwe, in Fossil Fuel Foundation (FFF) Workshop, Johannesburg, South Africa, May 11, 2016, Proceedings: Fossil Fuel Foundation, accessed September 13, 2016, at http://www.fossilfuel.co.za/courses/2016/ Gas-Workshop/3/CBM-Potential-RSA-Bots-Zim-FFF-11th-May_greg-dowling.pdf.

IHS Markit ${ }^{\mathrm{TM}}$, 2015, International petroleum exploration and production database [current through December 2015]: IHS Markit,

15 Inverness Way East, Englewood, CO 80112.

McConachie, Bruce, comp., 2015, Independent geologist's report CBM licenses in Botswana: Brisbane, Queensland, Australia,

Tlou Energy, and London, United Kingdom, Brandon Hill Capital and Grant Thornton, 53 p., accessed September 13, 2016, at http://tlouenergy.com/wp-content/uploads/2015/10/Tlou_AIM_Admission_Competent-Persons-Report.pdf. [Prepared by SRK Consulting (Australasia), Brisbane, Queensland, Australia, project number TLO004.]

\section{Kalahari Basin Province Assessment Team}

Michael E. Brownfield, Christopher J. Schenk, Timothy R. Klett, Marilyn E. Tennyson, Tracey J. Mercier, Stephanie B. Gaswirth, Kristen R. Marra, Sarah J. Hawkins, Thomas M. Finn, Phuong A. Le, and Heidi M. Leathers-Miller

\section{For More Information}

Assessment results also are available at the USGS Energy Resources Program website at http://energy.usgs.gov. 